\title{
ОСОБЕННОСТИ ГОСУДАРСТВЕННОГО КОНТРОЛЯ И НАДЗОРА В ТУРИСТСКОЙ ДЕЯТЕЛЬНОСТИ. ЕДИНАЯ ИНФОРМАЦИОННАЯ СИСТЕМА ЭЛЕКТРОННЫХ ПУТЕВОК
}

\author{
(C) 2019 Батурин Андрей Андреевич \\ магистр \\ ИГСУ РАНХиГС, Россия, Москва \\ E-mail: aabaturin94@yandex.ru
}

\begin{abstract}
Статья посвящена проблемам туристской деятельности, связанными с невозможностью профессиональных участников рынка само регулировать свою работу. Из-за их недобросовестных действий увеличилось количество нарушений прав туристов, которые потеряли свои денежные средства. Кроме того, в отрасли стало появляться большое количество «серых схем» из-за чего страдают как граждане, чьи права нарушаются, так и государственный бюджет, который не дополучают часть денежных средств от сбора налогов за реализованный туристских продукт.

Автор рассматривает каким образом и за счет каких механизмом контроля и надзора государство будет нормализовать работу отрасли и защищать права граждан. В частности, речь идет об единой информационной системе электронных путевок.

Ключевые слова: государственный контроль и надзор, туристская деятельность, единая информационная система электронных путевок, защита прав туристов, недобросовестные профессиональные участники туристского рынка.
\end{abstract}

В условиях стремительного развития туризма во всем мире и его огромного вклада в мировую экономику, меняются и особенности государственного контроля за этой отраслью. С одной стороны - туризм позволяет привлечь новые средства в экономику, развивать инфраструктуру, создавать новые рабочие места, повышать благосостояние граждан. С другой - это сложная, разветвлённая сеть, контроль за которой с каждым годом становится все сложнее. Отсюда и увеличение нарушений прав туристов, банкротства туристических фирм, оказание услуг ненадлежащего качества. Именно поэтому вопрос о регулировании отрасли с каждым годом становится все острее. Особенно это касается России, так как в нашей стране туризм один из немногих рынков, который остается практически на саморегулировании. И чем дольше это происходит, тем существеннее будет эффект передачи полномочий регулирования от профессиональных участников рынка (туроператоров и турагентств) к государственному регулятору.

На данный момент основные задачи, которые стоят перед государством: обеление отрасли, в связи с развитием серых схем, а также занижением со стороны турфирм реального количества реализованного ими туристского продукта, что негативно сказывается как на государстве - бюджет не дополучает большую часть средств от налогов с туризма, так и на туристах, которые в случае банкротства турфирм либо остаются за границей и не получают своевременную помощь по возврату, либо не получают компенсацию за предстоящий тур.

Процесс по решению этих проблем затянулся, в связи с передачей 14 сентября 2018 года Федерального агентства по туризму от Министерства культуры РФ в Министерство экономического развития РФ. Потребовалось время, чтобы изучить ситуацию, а также выработать новые механизмы по обелению отрасли и защиты прав туристов. Была принята «Стратегия развития туризма в России до 2035 года». «Стратегия направлена на развитие внутреннего и въездного туризма за счёт создания и развития туристских территорий специальных преференциальных режимов, реализации комплексных проектов создания туристской и обеспечивающей инфраструктуры, формирования и продвижения качественного и конкурентоспособного туристского продукта на внутреннем и международном туристских рынках, увеличение доступности туристских услуг, отдыха и оздоровления для российских граждан» [2]. Первым шагом в данном процессе станет внесение изменений в ФЗ «Об основах туристской деятельности в Российской 
Федерации» от 24.11.1996 № 132-Ф3, который за почти 25 лет не претерпевал особых изменений и, по мнению всех участников рынка, давно требует обновления. Кроме того, необходимо пересмотреть механизм финансовых гарантий.

В настоящий период в Российской Федерации действуют 3 инструмента гарантий обеспечения прав туристов при несостоятельности (банкротстве) туроператоров: страхование (фингарантии), отчисления в резервный фонд и фонд персональной ответственности туроператоров.

При банкротстве туроператора туристам не обеспечивается возмещение реального ущерба. Указанное обусловлено, с одной стороны, неэффективностью и сложностью администрирования действующих трех инструментов, с другой стороны, указанная неэффективность существенно усугубляется занижением туроператорами общей цены турпродукта, от которой рассчитываются размеры фингарантий (страхование) и взносов в фонды.

Анализ банкротств туроператоров в сфере выездного туризма - «Натали Турс», «DSBW Турс», «Матрешка Тур», «Премиум Тревэл Групп», «Аврора БГ», «Полар Тур», «Радуга Трэвел» и других выявил, что действующие инструменты защиты прав туристов (фингарантии ответственности туроператоров, резервный фонд и фонд персональной ответственности туроператоров) не способны в должной мере обеспечить защиту имущественных прав туристов.

Так, свыше 19 тыс. клиентов «Натали Турс» (выездной туризм - ООО «Панорама Тур» и ООО «Агентство путешествий «Натали», а также специализирующееся на внутреннем туризме ОоО «Туроператор «Натали Турс») направили требования ее финансовому гаранту - страховщику «Ингосстрах» о выплате компенсаций более чем на 1 млрд. руб. Ответственность первых юрлиц была застрахована в «Ингосстрахе» на 50 млн. руб., третьего - 500 тыс. руб.

С целью увеличения эффективности инструмента фингарантий и фондирования, а также обеления рынка было принято решению возобновить эксплуатацию единой информационной системы электронных путевок (далее - Система). Она была разработана Ростуризмом в 2017 году, но из-за неготовности нормативной правовый базы сроки его внедрения переносились. Для этого в 2019 году Правительством Российской Федерации были приняты Постановления от 08.06.2019 г. № 747 «Об утверждении Правил создания и функционирования единой информационной системы электронных путевок, структуры единой информационной системы электронных путевок и условий предоставления содержащейся в единой информационной системе электронных путевок информации» и от 08.06.2019 г. № 748 «Об утверждении требований к использованию документов в электронной форме туроператором, турагентом и туристом и (или) иным заказчиком при реализации туристского продукта и Правил обмена информацией в электронной форме между туроператором, турагентом и (или) иным заказчиком при реализации туристского продукта».

Из данных нормативных правовых актов следуют выделить цели внедрения и функционирования Системы:

1) обеспечение защиты прав потребителей туристского продукта,

2) повышение эффективности государственного регулирования в сфере туризма,

3) автоматизация процессов сбора и обработки статистической, оперативной, аналитической и иной информации о туристском продукте.

Внедрение и функционирование Системы направлено на решение следующих задач:

1) обеспечение прозрачности деятельности туроператоров и турагентов при заключении договоров о реализации туристского продукта;

2) предупреждение случаев неисполнения туроператором и (или) турагентом обязательств по договорам о реализации туристского продукта и нарушений прав туристов;

3) обеспечение эффективной защиты прав туристов в случае неисполнения туроператором и (или) турагентом обязательств по договорам о реализации туристского продукта, в том числе в результате прекращения деятельности туроператора;

4) обеспечение оперативного мониторинга деятельности участников туристского рынка [3].

Электронная путевка гарантирует, что обязательства туроператора имеют финансовое обеспечение, достаточное для ведения туроператорской деятельности. С квитанцией электронной путевки можно будет обращаться в фонд персональной ответственности туроператора при Ассоциации «Турпомощь» в случае невыполнения туроператором своих обязательств.

Система обеспечит прозрачность туристского рынка, вывод его значительной части из тени. 
Так, по оценкам Банка России, объем продажи туроператорами и турагентами полученных от туристов наличных денежных средств (как часть системы обналичивания) в 2017 году составил порядка 22 млрд.рублей. Значительная часть проданной наличности не отражается в качестве выручки для целей налогообложения. Поскольку большая часть турагентов и туроператоров находится на УСНО, эффективные инструменты контроля соответствия реальной выручки (общей цены реализации турпродукта) с отражаемой в бухгалтерской и налоговой отчетности отсутствуют (в отличие, например, от администрирования НДС при ОСНО).

Система упростит процедуры учета и контроля за реализацией турпродукта, в том числе в части цены турпродукта, минимизирует возможность использования недобросовестными участниками туристического рынка «серых» схем в ущерб прав и законных интересов туристов.

В свою очередь, увеличение прозрачности туристического рынка и вывод его из тени, позволит:

1) актуализировать расчеты нормативов фингарантий и фондирования для туроператоров, сделав их более точными с учетом всех критериев (общая цена реализации турпродукта за предшествующий период, глубина продаж, и прочие);

2) повысить налогооблагаемую базу туроператоров и турагентов.

В будущем представляется необходимым поэтапно упростить механизм финансового обеспечения защиты прав туристов: отменить взносы туроператоров в малоэффективные фонды и страхование, ввести фиксированный взнос с каждой электронной путевки в единый фонд по аналогии с международной практикой. За счет таких взносов туристы будут застрахованы от форс мажорных обстоятельств, связанных с банкротством авиакомпаний, отелей и туроператоров. Кроме того, снизится финансовая нагрузка туроператоров по уплате взносов в фонды и на фингарантию. Средства единого фонда сверх установленных минимумов могут быть направлены не только на защиту прав туристов, но и на льготное кредитование туроператоров, поддержку инновационных проектов в сфере внутреннего и въездного туризма.

Подобный единый инструмент обеспечения, средства по которому будут собираться непо- средственно при оформлении электронной путевки с туриста (а, например, не рассчитываться постфактум от цены реализованного турпродукта за предыдущий год) упростит администрирование и исключит проблемы для туроператоров по страхованию. Так, в связи с приостановлением в конце октября 2018 г. Банком России действия лицензии страховой компании «Якорь» без фингарантии осталось 455 туроператоров (более 15\% от всех компаний, зарегистрированных в реестре туроператоров), которым крайне сложно в установленный 45-дневный срок найти нового страховщика - вследствие высоких рисков страховщики не заинтересованы в данном виде страхования.

В Российской Федерации отсутствует единая система сбора статистической информации во всех сферах туризма. Система направлена на решение данной проблемы, поскольку достоверные статистические данные являются важным условием при выработке государственной политики и нормативно-правовом регулировании сферы туризма, разработке программ поддержки внутреннего и въездного туризма (в рамках нацпроекта по экспорту услуг, ФЦП).

Для внедрения Системы и его запуска в промышленную эксплуатацию группа депутатов Государственной Думы 7 ноября 2019 года внесли законопроект «О внесении изменений в Федеральный закон «Об основах туристской деятельности в Российской Федерации». Согласно документу с 1 апреля 2020 года Система становится обязательной для всех туроператоров, а «реализация туристского продукта без формирования электронной путевки и размещения сведений о ней в единой информационной системе электронных путевок запрещается и влечет за собой административную ответственность в соответствии с законодательством Российской Федерации» [4].

Однако, данные изменения ожидаемо были встречены жесткой критикой со стороны туроператоров во время публичных обсуждения проекта закона перед первым чтением в Государственной Думе. Российский союз туриндустрии направил открытое письмо в адрес Председателя Государственной Думы В.В. Володина со своей позиции относительно предстоящих изменений. В первую очередь, туриндустрия была не согласна со слишком сжатыми сроки введения обязательности. Кроме того, непонятно какой будет размер платы на Систему, и кто будет за 
нее платить профессиональные участники рынка или туристы. Как будет отслеживаться не внесение данных о туристском договоре в Систему? В связи с этим, законопроект был отравлен на доработку и до сих пор непонятно, когда будет снова отправлен в Государственную Думу.

Однако, не смотря на неудачную первую попытку, прослеживаются положительные тенденции в особенностях государственного контроля и надзора в туристской деятельности. В первую очередь, это связано с пониманием сложившейся ситуации и её основных проблем. Саморегулирование туристского рынка не показало сво- ей эффективности, действующие механизмы не справляются с поставленными перед ними задачами, от этого страдают все участники рынка, кроме тех, кто использует «серые схемы» и нарушает права туристов. Введение такого механизма как единая информационная система электронных путевок - первый шаг государства на пути решения вышеуказанных проблем. Её введение позволит в кратчайшие сроки собрать необходимую информацию, проанализировать её и реально оценить ситуацию на рынке для выработки дальнейших шагов по его контролю.

\section{Библиографический список}

1. Федеральный закон «Об основах туристкой деятельности в Российской Федерации» от 24.11.1996 № 132Ф3 // Собрание законодательства РФ. - 1996. - № 49. - Ст. 5491.

2. Распоряжение Правительства РФ от 20.09.2019 № 2129-р «Об утверждении Стратегии развития туризма в Российской Федерации на период до 2035 года».

3. Постановление Правительства РФ от 08.06.2019 г. № 747 «Об утверждении Правил создания и функционирования единой информационной системы электронных путевок, структуры единой информационной системы электронных путевок и условий предоставления, содержащейся в единой информационной системе электронных путевок информации».

4. Проект Федерального закона от 07.11.2019 № 831599-7 «О внесении изменений в Федеральный закон «Об основах туристской деятельности в Российской Федерации».

5. Егоров В.E. О некоторых правовых вопросах организации деятельности отдельных субъектов туризма в регионах Российской Федерации // В.Е. Егоров / Туризм: право и экономика. - 2017.- № 4.

6. Писаревский Е.Л. государственное и муниципальное управление в сфере туризма: учебник // Е.Л Писаревский / Федеральное агентство по туризму.- Москва. - 2014.

7. Сирик Н. Оказание туристских услуг: гражданско-правовое регулирование // Н. Сирик / Наука и Образование. -2013.

8. Накушнова Е.В. Вопросы гражданско-правового регулирования оказания туристских услуг в Российской Федерации // Е.В. Накушова / Туризм: право и экономика. - 2016. - № 2. 